\title{
KIELI, TUO VIEKAS SEURALAINEN
}

Irina Piippo, Johanna Vaattovaara ja Eero Voutilainen: Kielen taju. Vuorovaikutus, asenteet ja ideologiat. Art House 2016.

"Ylpeä luulee käyttävänsä kieltä. Viisaus alkaa sen tajuamisesta, kuinka viekkaasti kieli käyttää meitä”, kirjoittaa Seppo Kahila teoksen Kieli on maailmasi (1980) takakannen aforismissa. Kahilan näkemystä seuraten kielen taju voitaisiinkin ymmärtää kieleen sisältyvän viekkauden paljastamiseksi, sellaisten kielenkäyttöön sisältyvien ilmiöiden hahmottamiseksi, jotka säätelevät vuorovaikutustilannetta ja sen tulkintaa, vaikka jäisivätkin ensi kuulemalta tiedostamattomiksi.

Kielen käyttöön liittyy voimakkaita tunteita ja asenteita. Yksittäiset ilmaisut tarttuvat korvaan ja pistävät silmään. Huonosta kielenkäytöstä pahastutaan, vääriä murteellisuuksia vierastetaan ja vierasperäisiä vaikutteita kammoksutaan. Pahastumisen, vierastamisen ja kammoksumisen asemesta on kuitenkin parempi kurkistaa hieman tarkemmin niihin periaatteisiin, joiden mukaan kieli toimii.

Irina Piippo, Johanna Vaattovaara ja Eero Voutilainen jäljittävät kirjassaan Kielen taju Kahilan mainitsemaa kielen viekkautta. Virallisemmin ilmaistuna kirjoittajat ajavat takaa "kokonaisvaltaista ymmärrystä siitä, mitä parhaillaan käytettävä kieli merkitsee juuri meneillään olevassa vuorovaikutustilanteessa”. Tarkastelun keskiössä on kielenkäyttöön liittyvä ideologisuus ja kielen indeksisyys eli kielen tilanteinen merkitys.

Kirjoittajien teoreettinen lähtökohta on sosiolingvistinen: kieli nähdään ennemmin dynaamisena toimintana kuin staattisena rakenteena tai kielioppina. Kieli ei ole sanakirjojen sivuille hakattu vaan se elää ja muuntuu jatkuvasti päivittäisissä kielenkäyttötilan- teissa. Ehkäpä kielen vapaa vellominen mitä erilaisimmissa yhteyksissä - muun muassa sosiaalisessa mediassa - onkin yksi syy, miksi kielen tajua tarvitaan juuri nyt kipeämmin kuin aikaisemmin.

Kirjan läpäisevän juonteen voi kiteyttää seuraavasti: minkälaisia merkityksiä tietty kielellinen valinta tuo mukanaan kielenkäyttötilanteisiin, joissa rakennetaan läsnäolijoiden yhteistä sosiaalista todellisuutta, ja miten näitä merkityksiä voi tehdä näkyväksi kielentutkimuksen keinoin. Minkälaisia tulkintoja esimerkiksi persoonapronomini mie herättää kuulijassa puhujan taustasta ja persoonasta? Tai minkälaisia tuntoja saa aikaan pitkän aikaa kirjakielessä pannassa ollut mutta sittemmin "vapautettu” muoto 'alkaa tekemään'? Tai miten suhtaudutaan naispuoliseen sähkömieheen? Konkreettisena aineistona kirjoittajat käyttävät muun muassa tietynlaista kielenkäyttöä kritisoivia mielipidekirjoituksia ja artikkeleja, mikä auttaa tarkastelemaan kielellisiä valintoja eri näkökulmista.

Tekijät määrittelevät kieli-ideologiat "tietoisiksi tai tiedostamattomiksi asenteiksi, mielipiteiksi, uskomuksiksi ja teorioiksi kielestä”. Ymmärrys kielestä on siten aina jonkinlainen ideologinen rakennelma, johon liittyy käsityksiä esimerkiksi oikeasta ja väärästä kielenkäytöstä. Jako oikeaan ja väärään kaventaa kielenkäytöstä piirtyvää kuvaa ja asettaa kielenkäyttäjiä tarpeettomasti keskenään eriarvoiseen asemaan.

Kielen asettamaan ideologiseen ansaan on hämmästyttävän helppo langeta. Kun arvioi kielentutkijoiden kirjoittamaa teosta ja havaitsee kirjan sivulla 84 kaksoispassiivin: "- - aikojen saatossa ollaan tultu tilanteeseen - -", on suuri kiusaus tarttua asiaan ja johdattaa ajatus pois itse aiheesta - tässä tapauksessa 
murreasenteista. Samalla on vapauttavaa tutkiskella omaa kiusaustaan kirjan antamien taustateorioiden, näkemysten ja esimerkkien valossa ja palata siihen, mistä Kielen tajussa oikeasti on kyse.

Luvussa Kielen kuva Irina Piippo johdattaa lukijat kirjan aiheeseen ja teoreettisiin lähtökohtiin. Luvun kainalojutun omainen napakka esittely sosiolingvistiikan eri tutkimussuuntauksista antaa hyvän näköalan siihen, millä tavoin kielen tajua voidaan lähestyä. Sosiolingvistinen variaationtutkimus, kansanlingvistiikka, keskustelunanalyysi, diskurssintutkimus ja lingvistinen antropologia ovat kaikki kiinnostuneita siitä, miten kieli, yhteisö, yhteiskunta ja kulttuuri kietoutuvat yhteen. Tutkimusmetodit ovat erilaisia, mutta niiden tavoitteena voidaan pitää samaa asiaa, joka kiteytyy luvun viimeisessä osiossa: kriittistä kielitietoisuutta.

Piipon mukaan kriittinen kielitietoisuus on luonteva osa toiminnallista kielitaitoa ja kykyä toimia sujuvasti erilaisissa käytännön vuorovaikutustilanteissa. Nykyään puhutaan paljon medianlukutaidoista ja mediakriittisyydestä. Koska suuri osa viestinnästä kuitenkin tapahtuu kielen varassa, kysymys vuorovaikutuksesta ja sen erittelevästä tarkastelusta on laajempi kuin vain viestimiin sidottu ilmiö. Kyse on kaikesta kielenkäytöstä.

Avausluku on sopivan provosoiva. Jos sen ottaisi ihan tosissaan, olisi uskaliasta avata suutaan missään tilanteessa - tai ainakin suuri osa vuorovaikutuksesta kuluisi sen miettimiseen, mitähän juuri tuli sanotuksi ja millä tavalla. Toisaalta kuva kielestä piirtyy avausluvussa juuri sellaiseksi, että sen tutkiskelu käyttöyhteyksissään alkaa kiinnostaa. Onhan jopa sanottu, että suurin osa maailman konflikteista ja erimielisyyksistä johtuu ihmisten tavasta pilkkoa ja luokitella maailmaa käsitteellisesti. Jos tarkastelun keskiössä olisivat enemmänkin luokitteluprosessien vaiheet kuin niiden lopputulokset, voisi vuorovaiku- tuksessakin kenties tapahtua kehitystä myönteiseen suuntaan.

Piipon, Vaattovaaran ja Voutilaisen yhteisesti kirjoittama toinen luku Koskaan et muuttua saa käsittelee aihetta, joka palaa aika ajoin lehtien yleisönosastokirjoituksiin ja kielenkäyttöä kommentoiville sosiaalisen median keskustelualueille. Nuorten, radiojuontajien ja muiden hulttioiden tapa käyttää kieltä vaikuttaa turmeltuneelta; uudennokset ja väännökset tuntuvat rappeuttavan kieltä. Puhekielisyydet tunkeutuvat kirjoitettuun kieleen, eikä millään taida olla enää mitään väliä, kun kaikkialla vain sometetaan ja biletetään. Asia ei ole kuitenkaan niin huolestuttava kuin ensi kuulemalta voisi päätellä - oikeastaan päinvastoin.

Asetelmassa ovat vastakkain ideologinen näkemys yhteiseksi koetusta vakaasta kielestä - useimmiten standardoidusta kansalliskielestä - ja kielen ominaispiirteisiin kuuluva muuttuminen. Kieli elää kaiken aikaa vääjäämättä, ja voikin kysyä, minkälainen olisi yhteiskunta, jossa kielenkäyttö olisi muuttumatonta ja tarkasti säädeltyä. Kenen kieltä käytettäisiin, ja kuka määrittelisi, miten asioista tulisi puhua?

Kirjoittajat esittelevät luvussa muutamia esimerkkejä kielen muutokseen pureutuvista tutkimusmenetelmistä ja sellaisista puhekielen piirteistä, joiden tiedetään tutkimusten perusteella olevan muutoksessa. Tällainen piirre on vaikkapa omistusliitteen väistyminen, joka Heikki Paunosen mukaan tulee luultavasti peittoamaan omistusliitteiset muodot vuoteen 2030 mennessä. Näin muoto minun kirja/mun kirja valtaa laajemman käyttöalan kuin muoto minun kirjani tai kirjani.

Sanastotason muutokset ovat rakennepiirteitä nopeampia. Kielen muutoksessa on kyse myös luovuudesta ja kielen rajojen koettelusta: kieli on terve, kun sillä voi leikkiä. Sanojen merkitysten muuttuminen, uusien sanojen käyttöönotto ja vanhojen sanojen käyttö uusissa yhteyksissä kertoo myös yhteiskunnalli- 
sesta toimeliaisuudesta. Niinpä sana vatulointi on jo osa suomalaista poliittista keskustelua ja sen merkitysala säteilee hyvinkin laajoihin valtakunnallisiin sfääreihin.

Johanna Vaattovaaran kirjoittama luku Vieraat ja vaaralliset sekä Eero Voutilaisen kirjoittama Paha pube liittyvät läheisesti kielen puhtautta ja muuttumattomuutta korostavaan ideologiseen kielikäsitykseen. Kielen elävässä elämässä lienee mahdotonta pitää erillään vieraita vaikutuksia ja puhekielen ilmiöitä - ja molempien yhteydessä on helppo jumittua vastakarvaiseen asenteeseen. Vieraat vaikutukset leviävät kielenkäyttöön usein juuri puhekielen välityksellä siirtyäkseen sitten mahdollisesti vähitellen myös kirjoitettuun kieleen. Vieraita aineksia ovat kuitenkin sanojen lisäksi myös vieraiksi koetut äänteelliset ilmiöt, kuten suomen kieleen änkeytyneet sitku, mutku japliis tai helsinkiläinen s-äänne.

Vaattovaara esittelee Dennis R. Prestonin kieliteorian, jonka mukaan tapa katsoa kieltä ylhäältä alaspäin (tässä tapauksessa jopa ikään kuin nenänvartta pitkin) on tyypillinen maallikoille (ei-lingvisteille). Lingvisteille puolestaan on ominaista tarkastella kieltä yksilöiden ja yhteisöjen käyttötilanteista ylöspäin rakentuvana ilmiönä. Vaattovaara suhtautuu Prestonin näkemykseen kriittisesti, sillä näkemyksissä on havaittavissa paljon keskinäistä vaihtelua. Se mikä toisen korvaan särähtää epäsuomalaisena, merkitsee toiselle itseilmaisua, olipa kuulijana sitten kansanlingvisti tai kouluttautunut kielentutkija.

Puhuttu ja kuultu kielen aines suhteutuu niihin yhteisöihin, jotka hahmottuvat kielenkäyttäjän omien viiteryhmien ja kokemusten kautta. Joissakin kieliyhteisöissä on oikein ja arvokasta käyttää vieraita sanoja ja vieraalta kuulostavia ilmaisutapoja. Samoja ilmiöitä voisi tarkastella siten myös toisinpäin: millä perusteella jotkin kielen piirteet osoittautuvat arvostetuiksi tietyissä viiteryhmissä. Asiaa lienee vaikea tutkia: kieleen kohdistuvat asen- teet todentuvat julkisessa keskustelussa useimmiten ilmeisesti juuri kielteisten mielikuvien kautta. Mitä se kertoo kieli-ideologioista?

Luvussa Murtuvat murteet ja murreasenteet tarkastellaan murteita osin myös myönteisten mielikuvien kautta. Yksi käsitys on, että murre edustaa kielenkäytön autenttisuutta ja alkuperäisyyttä. Ei ole kovinkaan kauan siitä, kun murrebuumi valloitti sarjakuvat; ensimmäinen murrealbumi oli Asterix-seikkailu Opeliksin orjalaeva 1990-luvun lopulla. Sen jälkeen esimerkiksi Aku Ankkaa on julkaistu yli kymmenellä murteella, muun muassa sarjana vuonna 2015. (Akkarin murresarja alkaa 2015.) Akkarin tapaus kertoo kiinnostavia asioita suomalaisten asenteista murteita kohtaan. Tutun sarjakuvahahmon murteellisissa puhekuplissa on pakko olla jotakin riemastuttavaa - ja lukijoiden odotuksia vastaavaa.

Johanna Vaattovaara tuo tekstissään esille sosiolingvistien nykynäkemyksen siitä, että murteet ovat pääosin kuviteltuja ja ne pitävät yllä eri kansanryhmiin liitettyjä stereotypioita. Savolaiset ovat lupsakoita ja eteläpohjanmaalaiset puukkojunkkarien sukua... Murteet eri kielenpiirteineen ja maantieteellisine esiintymisalueineen ovat toki olemassa murretutkijoiden haastatteluissa ja kartoissa, mutta ne mielikuvat, jotka murteisiin liitetään, ovat alkaneet elää omaa elämäänsä. Murre-Akkarit on tästä osin hyytäväkin esimerkki. Murteisiin liittyvien mielikuvien vaarana saattaa olla jonkinlainen päinvastainen autenttisuus. Jos savo kuulostaa Aku Ankan suussa hauskalta, voi syntyä mielikuva, että kaikki savoksi puhuttu on hauskaa. Miten sen jälkeen länsisuomalainen enää osaa ottaa todesta kuopiolaista, joka alkaa puhua henkilökohtaisista ongelmistaan omalla murteellaan?

Eero Voutilaisen kirjoittama luku Kielenohjailu on politiikkaa vie kieleen liittyvän ideologisuuden perimmäisten asioiden äärelle. Kielen muuttumista, vieraita aineksia ja puhekieltä peilataan yleisimmin juuri viralli- 
sesti ohjailtuun ja standardisoituun yleiskieleen. Monen kielenkäyttäjän mielessä saattaa kielikalabaliikkia herättää aikaisemmin käytössä ollut termi oikeakielisyys ja siihen muistin sopukoissa kytkeytyvä punakynää käyttäneen äidinkielenopettajan haamu.

Nykyisin käytössä oleva termi kielenhuolto on sävyltään neutraalimpi, ja sen yhteydessä esitetään mieluummin suosituksia kuin sääntöjä. Jo se mitä sanoja virallinen kielipolitiikka käyttää toiminnastaan, vaikuttaa kieltä koskeviin mielikuviin ja asenteisiin - ja termejä toisiksi vaihtamalla niihin pyritään vaikuttamaan.

Voutilainen erottaa kuusi erilaista kielenohjailun taustalla olevaa ideologista suuntausta, jotka eivät kuitenkaan liity yksinomaan kieleen vaan ihmisyhteisöihin yleisimminkin. Ideologiat ovat konservatismi, liberalismi, nationalismi, internationalismi, populismi ja egalitarismi. Viimeistään kirjan tässä vaiheessa on selvää, ettei kielenkäyttöä eikä sen taustalla vaikuttavia ajankohtaisia yhteiskunnallisia ilmiöitä voi erottaa toisistaan.

Siinä missä konservatiivinen kielipolitiikka pyrkii säilyttämään kielen ikään kuin puhtaana ja alkuperäisenä, liberalismi antaa tilaa alueelliselle, sosiaaliselle ja tilanteiselle vaihtelulle. Suomalainen kielenohjailu on Voutilaisen mukaan liberaalimpaa tai ainakin vähemmän konservatiivista kuin Unkarissa, missä yleiskielen hallinnoimisessa on varsin autoritaarinen ote.

Englannin kielen varassa kehittynyt tietotekniikan alan kieli on esimerkki nationalismin ja internationalismin välisestä ristivedosta. Pitäisikö tietyn alan termit suomentaa tai suomalaistaa, vai voiko niiden asemesta käyttää alkukielisiä termejä tai niiden väännöksiä? Internetissä surffaus voi kuulostaa oudolta maassa, jossa meren aalloilla ratsastaminen ei ole yhtä tuttua kuin Piilaakson rannikolla, jolta suuri osa alan termistöstä on peräisin. Joskus surffauksen suomenkieliseksi vastineeksi onkin tarjottu sanaa samoilu, joka siirtäisi ajatuksen vapaasta liikkumisesta www-sivulta toiselle suomalaiseen kontekstiin. Monesti nationalismin ja internatiolismin yhteydessä törmätään ilmeisesti siihen pohdintaan, miten nopeasti jonkin alan terminologia vakiintuu osaksi yleiskieltä. Alan ammattilaiset tuskin olisivat ymmärtäneet missään vaiheessa, mitä internetissä samoilu tarkoittaa.

Populismissa korostuu Voutilaisen mukaan tunne- ja vaistopohjainen suhtautuminen kieleen ja epä-älyllinen vetoaminen kansan etuihin ja tahtoon. Egalitarismissa sen sijaan kielen ohjailua tarkastellaan tasa-arvon ja osallisuuden näkökulmasta. Tavoitteena on kielellinen demokratia. Esimerkkinä Voutilainen käyttää Kotimaisten kielten keskuksen valtion virastojen kanssa toteuttamaa virkakielen kehittämisohjelmaa.

Luvussa Kabden kerroksen väkeä Irina Piippo vie kieli-ideologisen tarkastelun astetta syvemmälle kuin aikaisemmat "kieliasenneluvut". Tavoitteena on tarkastella, miten sukupuoli näkyy kielessä ja kielenkäytössä ja miten siten luodut mielikuvat pitävät yllä jakoa miehiin ja naisiin, muun muassa miesten töihin ja naisten töihin, miesten ja naisten asemaan yhteiskunnassa.

Aihetta voi lähestyä yksittäisten sanojen kautta tai laajemmin erilaisten tekstien tai kielellisen vaihtelun avulla. Kenties helpoin tapa tarttua aiheeseen on suomen kielen -miesloppuiset sanat, jotka kategorisoivat tietyn tyyppiset ammatit tai tehtävät tietylle sukupuolelle ikään kuin luonnostaan kuuluviksi (lautamies, puhemies, perämies...). Samanlaisista kategorioista kertovat ilmaisut naissotilas ja miessairaanhoitaja. Toinen käytetty lähestymistapa on eritellä ja vertailla miesten ja naisten kielenkäyttöä. Piippo purkaa kyseisen asetelman; sen taustalla vaikuttaa ideologinen oletus siitä, että miesten ja naisten kielenkäytön välillä olisi eroa - vaikka näin ei todellisuudessa tutkimusten mukaan ole. 
Esimerkin kahden kerroksen väestä saattoi lukea Joensuun kaupungin työpaikkailmoituksesta syksyllä 2016. Ilmoituksessa haettiin elinvoimajohtajaa ja hyvinvointijohtajaa ja johtajilta toivottiin, että"egosi pystyy kannattelemaan myös hieman löysempää solmiota”. Kiivaan sosiaalisessa mediassa käydyn keskustelun jälkeen teksti muutettiin muotoon ”Täällä ei tarvitse kulkea nuttura, rusetti, solmio tai villapipo kireällä - pääasia, että sinusta löytyy joensuumaista johtaja-asennetta”. (Ahjopalo 2016.) Piippo korostaa, ettei kieli aseta sukupuolittuneita pakkopaitoja käyttäjilleen. Joensuun kaupungin ilmoituskampanja osoittaa, miten vaikea kielellisiä stereotypioita on välttää. Vaikka kampanjaa oli ollut suunnittelemassa sekä miehiä että naisia, sukupuolittuneet valtarakenteet ja niiden ilmaisut ovat kielessä jo valmiina vaanimassa.

Päätösluvussa Oppia ikä kaikki Irina Piippo ja Johanna Vaattovaara kokoavat yhteen teoksen teemat ja pohtivat niitä kielenopetuksen ja omaksumisen näkökulmasta. Miten äidinkielen ja vieraan kielen opetus eroavat toisistaan? Mitä on kielitaito, ja miten sitä voidaan tukea? Miten monikielisyys vaikuttaa suomalaiseen kielimaisemaan? Minkälaiset kieli-ideologiat vaikuttavat kielenopetuksen taustalla?

Piipon ja Vaattovaaran käsittelemät kysymykset ovat visaisia, ja vastausten löytäminen niihin on elintärkeää nykyisessä mosaiikkimaisessa kielimaisemassa - niin Suomessa kuin muuallakin. Kielenoppimiseen liittyvät kielikäsitykset saattavat olla todellisuudelle kovinkin vieraita, niin kuin voi lukea esimerkiksi Helsingin Sanomien jutusta, jossa otsikon mukaan Rovion entinen johtaja "päätti opiskella kiinan kahdeksassa viikossa" (Paakkanen 2016).

Riveiltä ja rivien välistä voi lukea kirjoittajien ideologiseksi sanomaksi sen, että kielen taju on ensiarvoisen tärkeää ja siihen olisi myös kielenopetuksessa kiinnitettävä entistä enemmän huomiota. Perinteinen kieliop- pipohjainen lähestymistapa ei ota tarpeeksi huomioon kielen kirjoa, dynaamisuutta eikä tilanteisuutta. Kirjoittajat päätyvät tekstissään lähes henkeäsalpaavaan visioon: "Kielen oppimisen, omaksumisen, opettamisen ja tutkimisen tarpeiden kannalta elettäneen parhaillaan vaihetta, jonka käänteentekevyyttä emme ehkä vielä tänä aikana kykene edes koko laajuudessaan hahmottamaan."

Piipon ja Vaattovaaran peräänkuuluttamaa kielen tajua voi kohentaa esimerkiksi lukemalla teoksen Kielen taju. Sen kuva kielestä on elävä ja monimuotoinen. Kirjoittajat ovat hyvin perehtyneitä aiheeseensa ja esittävät näkemyksensä tinkimättömästi. Samanlaista tarkastelutapaa voisi jatkaa vaikkapa politiikan kielen tai viranomaiskielen tarkasteluun. Ehkäpä käyttökelpoisin tapa lukea kirjaa on etsiä samalla kulloiseenkin aiheeseen sopivia ajankohtaisia esimerkkejä ja vertailla ja analysoida niitä kirjan antaminen suuntaviivojen avulla.

Irina Piipon, Johanna Vaattovaaran ja Eero Voutilaisen Kielen taju on yleistajuinen teos, niin kuin aihepiiriin erinomaisesti sopii. Sitä voi suositella kaikille kielenkäytöstä kiinnostuneille, niin alan tutkijoille kuin opettajille, opiskelijoille kuin tutkijoiksi aikoville. Tutkijoille ja opettajille teos tuskin tarjoaa kovinkaan paljon uutta tietoa, mutta opiskelijoille ja tutkijoiksi aikoville se on helposti avautuva kokonaisesitys kielestä ja sen toiminnasta.

Laajemmin tarkastellen kirjan tulisi olla pakollista luettavaa kaikille, jotka käyttävät kieltä päivittäisessä elämässään. Kielestä ei pääse irti, joten olisi hyvä tietää ja ymmärtää, minkälaisen ilmiön kanssa olemme tekemisissä. Niin kuin Pentti Saarikoski on asian ilmaissut: "Suomen kieli on minulle ikkuna ja talo. Minä asun tässä kielessä. Se on minun ihoni."

\section{Pasi Lankinen}

suomen kielen ja viestinnän yliopettaja

Metropolia Ammattikorkeakoulu pasi.lankinen@metropolia.fi 


\section{LÄHTEET}

Ahjopalo, J. (2016). Tasa-arvon tuulet puhalsivat Joensuun työpaikkailmoitukseen - naisLegot kokouspöytään. Yle. http://yle.fi/ uutiset/3-9149619. Päivitetty 7.9.2016. Luettu 30.10 .2016 .

Akkarin murresarja alkaa. Aku Ankka. <http:// www.akuankka.fi/artikkeli/tietolaari/ ajankohtaista/akkarin_murresarja_alkaa.> Laadittu 13.1.2015. Luettu 30.10.2016.

Paakkanen, M. (2016). Rovion jättänyt Vesterbacka päätti opiskella kiinan kahdeksassa viikossa - nyt hän haluaa kielen Suomen päiväkoteihin. Helsingin Sanomat. http://www.hs.fi/ talous/a1473655432672. Päivitetty 13.9.2016. Luettu 30.10.2016. 